\title{
DuneWatch: Launching citizen science for sandy dunes on the Gold Coast, Queensland, Australia
}

Maggie Muurmans, Peta Leahy and Rosalinde Brinkman

Griffith Centre for Coastal Management, Griffith University, Gold Coast, Australia

gccm@griffith.edu.au

\begin{abstract}
:
DuneWatch is a citizen science project established in 2015 by the Griffith Centre for Coastal Management. It provides an opportunity for community members to assist in collecting vital information on the health of the sand dunes. Data is collected at eleven sites along the Gold Coast coastline with each site visited within a 4-week period. The program monitors the impact of BeachCare's community planting days as well as helping to create adaptive management strategies for implementing species density and diversity, through the collection of data - Flora, fauna, human impact and slope measurements.

Data collected through the DuneWatch program will expand our knowledge of the local dune system as well as monitor the progress of BeachCare. DuneWatch has the potential to be undertaken as a citizen science program for other coastal community and land care groups nationally.
\end{abstract}

Keywords: Citizen Science, Sandy Dunes, Community engagement, Gold Coast region, DuneWatch

\section{Introduction:}

The City of Gold Coast is home to $52 \mathrm{~km}$ of coastline and includes approximately 763,000 $\mathrm{m}^{2}$ of sandy dunes (not including The Spit and South Stradbroke Island). BeachCare, established in 2005, saw the instigation of community planting on a number of Gold Coast beaches. The program currently has ten sites that are visited regularly by community members to revegetate and weed. The program instils environmental stewardship and ownership of the local ecosystem by a group of community members. In order to optimise the planting efforts and evaluate plant diversity, DuneWatch was launched in 2015 as the Griffith Centre for Coastal Management's in-house citizen science program. DuneWatch has created a partnership between coastal engineers and the community to strengthen the city's research capacity, solving real world problems and enhancing the local awareness of science.Similar to other citizen science projects, DuneWatch invites the public in both scientific thinking and data collection (Cooper et al. 2007a, Irwin 2001). There are currently 260.000 Australians active in over 215 registered citizen science projects in the country. The DuneWatch program continues on the principle of community engagement through data collection on the density and diversity of the biodiversity, profile and human impact of the dunes. It also provides an 
educational component to teach participants about native dune vegetation, invasive species, local pressures and disturbances to the dune sites.

Information on coastal health with regards to sand dune systems is a high priority with the health of the Gold Coast's dunal system rapidly declining (Allen \& Callaghan, 2000). This information could be collected through coastal behaviour observation methods. Obtaining information on Gold Coast's sand dune health will assist in its control and management. Using citizen science as a platform creates more awareness which could assist in the reduction of human pressures on this environment.

This paper will outline the DuneWatch program and considers its potential as a citizen science program which could be adopted more widely.

\section{DuneWatch Study Sites}

DuneWatch surveys are undertaken at ten different study sites along the Gold Coast. These sites are dune vegetation planting sites selected by the Griffith Centre for Coastal Management's BeachCare program which is in partnership with the City of Gold Coast. The ten sites are situated at the following locations and are shown in figure 1 :

- $\quad$ Paradise Point (Abalone Avenue)

- Runaway Bay (Shearwater Esplanade)

- Labrador (Close to Charis Seafood)

- Surfers Paradise (Aubrey Street)

- $\quad$ Broadbeach (Australia Avenue)
- North Burleigh (Kelly Avenue)

- Rainbow Bay (Marine Parade)

- Palm Beach (Lacey's Lane)

- Currumbin (Duringan Street)

- Bilinga (Sea Street)

DuneWatch surveys initiated on the $23^{\text {nd }}$ of October 2015 and are monitored every Saturday at one of the dune vegetation planting sites. Each site will therefore be surveyed every 10-weeks.

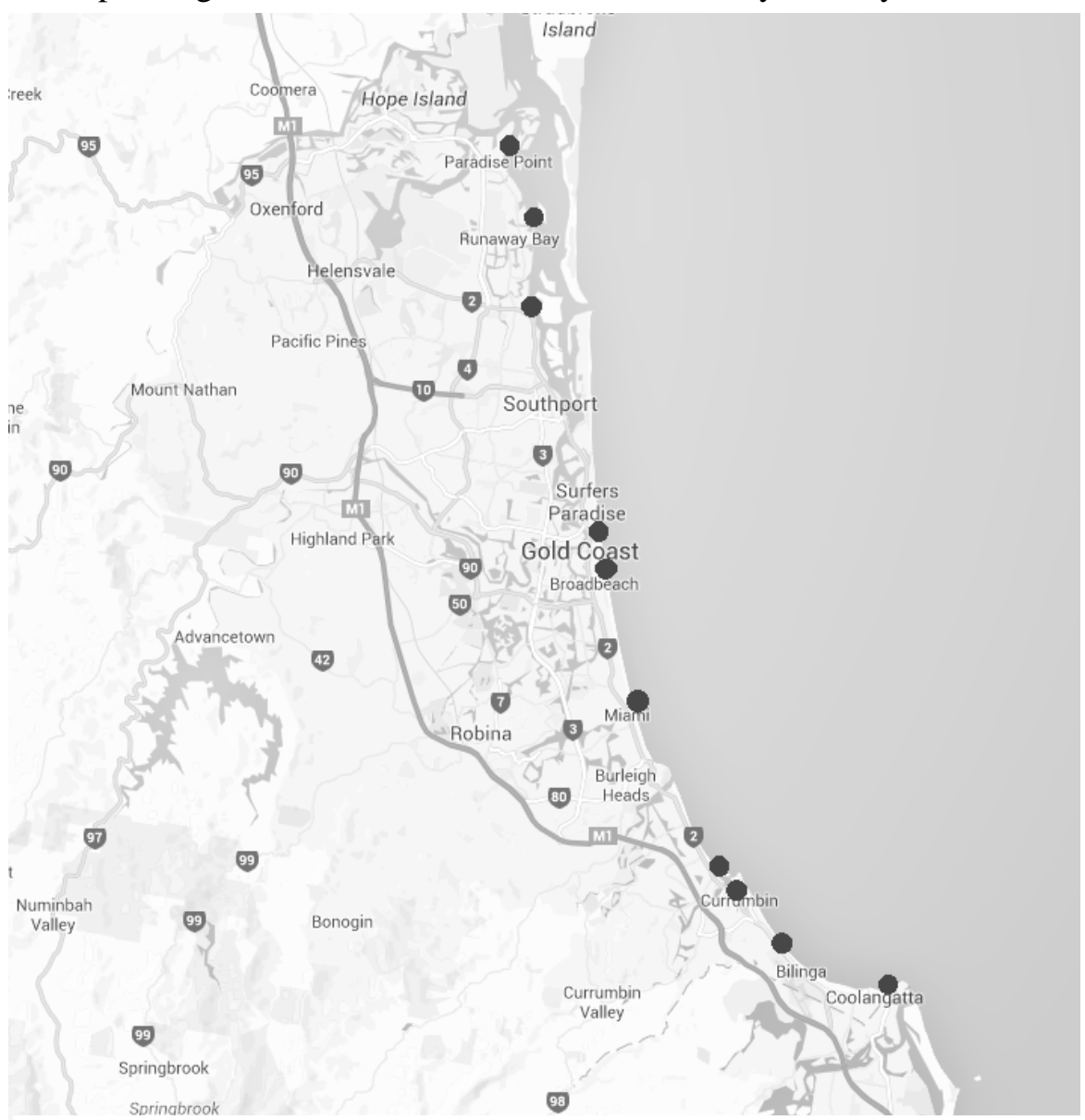

Figure 1: DuneWatch study sites on the Gold Coast indicated by dots (Source: Google Maps, 2015) 
MethodologyDuneWatch includes a number of different surveys as multiple elements require assessment. Surveys collect data on flora biodiversity and density; fauna biodiversity and density; slope profile; human impact; revegetation effort; invasive species and volunteer effort.

The dune flora density and diversity is assessed by applying line transects and quadrat surveys. A total of five transect lines and 50 quadrat surveys conducted at each study site. All vegetation within each quadrat is identified and recorded. Density is recorded in percentages per species (Wilson et al. 1996). Data on fauna biodiversity and density is collected through opportunistic observation, and counting of crabholes in combination with line transects. To measure the slopes and profile of the dune site, the emery method is employed at each location. Additional change of the dune site's profile and vegetation cover is recorded through photo point monitoring, where a photo is taken at the exact same location at each site (Hughes et al. 2009). Opportunistic observations were employed to collect information with regards to human impact (e.g. litter, trampling, etc.) at each site. Data on coastal works, weather conditions, volunteer attendance and plant species revegetated are also collected for each site. The weight of rubbish and weeds are also recorded for each location.

\section{Analysis and data processing}

The diversity and density for the flora surveys were calculated through the Simpsons D and Simpsons E indices (Beals, Gross and Harrell, 1999). A species lists was updated after each survey on native and invasive species found at each location.

Measurements of the slopes and analysis of the dune profile are calculated to obtain the height above sea level. When using the emery-method, the first calculation applied was the height above sea level in centimetres plus the difference between the two measuring poles in centimetres. Secondly, the difference between the two measuring poles divided by crossshore was applied to calculate the slope.

Changes for each dune site will be shown using a photo collage per study site. The photo collage will be an ongoing data base and established via the photo point monitoring method. Photos are displayed in chronological order resulting in a time-lapse. As a result, conclusions can be made through observations of the photos and pairing these with additional data gathered at each study site (for example coastal works, weather, etc.). Additionally, grids can be used in order to calculate the changes (Department of Environment and Resource Management, 2010).

The human impact surveys are analysed by data comparison between study sites.

\section{Results}

For the purpose of this paper, results concentrate on species diversity and the health of each dune site. Results for this paper are analysed for the first 5-months of the program (October 2015- March 2016). 


\section{Paradise Point}

The Paradise Point sand dunes are short in comparison to other sand dunes on the Gold Coast. This results in limited transect length and number of quadrats. A total of five species of flora have been observed. All these species can be found in the Poaceae family (table 1). Of these five species, two are weeds. The weeds are known as Cynodon dactylon (Couch grass) and Paspalum notatum (Bahia grass). The Paradise Point sand dunes are narrow and revegetation has just commenced. Information on flora density, diversity and distribution is therefore currently limited. However, the flora density did expand between the two visits. Additionally, the sand moves considerably fast as a result of minor flora density cover on these sand dunes. The fauna observed is limited. The horsetail she-oak provides shelter to number of bird species. The health of this sand dune can be considered poor as there is a low abundance in both flora and fauna. More planting should be realised in order to establish more biodiversity.

Table 1: Flora species list Paradise Point sand dunes

\begin{tabular}{|l|l|l|l|l|c||}
\hline Order & Family & Genus & Species & Common Name & Weed \\
\hline Poales & Poaceae & Cynodon & dactylon & Couch grass & $\mathrm{x}$ \\
\hline & & Eragrostis & interrupta & Coastal Lovegrass & \\
\hline & & Paspalum & notatum & Bahia grass & $\mathrm{x}$ \\
\hline & & Spinifex & sericeus & Beach spinifex & \\
\hline & Sporobolus & virginicus & Salt couch & \\
\hline
\end{tabular}

Fauna species found at the Paradise Point sand dunes are Manorina melanocephala (Noisy miner), Trichoglossus moluccanus (Rainbow lorikeet), Chroicocephalus novaehollandiae (Silver Gull) and animals of the suborder Caeliferam, also known as grasshoppers. A total of two crabholes were found during the first visit and 30 crabholes were observed during the second visit.

\section{Runaway Bay}

The Runaway Bay sand dunes are high in flora density, but low in biodiversity. This is the result of a large amount of weeds. The biodiversity exponentially decreased over the three visits. A decrease in the number of crabholes has also been observed, a sign of an increase in human impact or decrease in dune health. The fore dune has very steep slopes, a sign of a lack in root systems in these fore dunes. Weeding should be a priority for this site as well as planting on the fore dunes. This sand dune is currently in a poor condition. A total of 24 species are directly observed within 11 families from nine orders (table 2). Of these 24 species, 11 species are weeds.

Table 2: Flora species list Runaway Bay sand dunes

\begin{tabular}{|l|l|l|l|l|c||}
\hline Order & Family & Genus & Species & Common Name & Weed \\
\hline Asparagales & Xanthorrhoeaceae & Dianella & congesta & Flax lily & x \\
\hline Asterales & Asteraceae & Bidens & pilosa & Cobblers peg & $\mathrm{x}$ \\
\hline & & Conyza & bonariensis & Flaxleaf fleabane & $\mathrm{x}$ \\
\hline & & Emilia & sonchifolia & Lilac tasselflower & \\
\hline & Goodeniaceae & Scaevola & calendulacea & Fan Flower & \\
\hline Caryophyllales & Aizoaceae & Carpobrotus & glaucescens & Pigface & \\
\hline & & Teragonia & teragonioides & New Zealand spinach & \\
\hline
\end{tabular}




\begin{tabular}{|c|c|c|c|c|c|}
\hline Fabales & Fabaceae & Acacia & sophorae & Coastal Wattle & \\
\hline & & Desmodium & tortuosum & Florida Beggarweed & $x$ \\
\hline & & Glycine & tomentella & Glycine & $\mathrm{x}$ \\
\hline & & Macroptilium & atropurpureum & Siratro & $\mathrm{x}$ \\
\hline & & Vigna & marina & Yellow Beach Bean & \\
\hline Oxalidales & Oxalidaceae & Oxalis & corniculata & Creeping woodsorrel & $x$ \\
\hline Pandanales & Pandanaceae & Pandanus & spiralis & Pandanus & \\
\hline \multirow[t]{8}{*}{ Poales } & Cyperaceae & Carex & pumila & Dune Sedge & \\
\hline & & Cyperus & aggregatus & sedge & $\mathrm{x}$ \\
\hline & Poaceae & Cynodon & dactylon & Couch grass & $x$ \\
\hline & & Eragrostis & interrupta & Coastal Lovegrass & \\
\hline & & Paspalum & mandiocanum & Broadleafed paspalum & $\mathrm{x}$ \\
\hline & & Paspalum & dilatatum & Paspalum grass & $\mathrm{x}$ \\
\hline & & Spinifex & sericeus & Beach spinifex & \\
\hline & & Sporobolus & virginicus & Salt couch & \\
\hline Proteales & Proteaceae & Banksia & integrifolia & Coastal Banksia & \\
\hline Solanales & Convolvulaceae & Ipomoea & pes-caprae & Goat's Foot & \\
\hline
\end{tabular}

Fauna species found at the Paradise Point dune site are Chroicocephalus novaehollandiae (Silver gull), Thalasseus bergii (Crested tern), Mictyris longicarpusand (Soldier crabs), animals of the suborder Caeliferam, animals of the order Lepidoptera and animals of the suborder Anisoptera. A total of 18 crabholes were directly observed during the first two visits, only two crabholes were observed during the third visit.

\section{Labrador}

As this study site is a new restoration site, biodiversity is still low. Increase in revegetation activities is required in order to establish an increase in flora biodiversity. Furthermore, fencing should be realised in order to provide protection for this vulnerable ecosystem. The biodiversity slightly decreased between the two visits as a result of an increase in weed cover. Therefore, more weeding should be carried out. An increase in observed crabholes was recorded, indicating a decrease in human impact.

A total of 15 species are directly observed within nine families from seven orders on the Labrador sand dunes (table 3). Of these 15 species, four species are weeds. The four weeds are known as Conzya Canadensis (Canadian fleabane), Macroptilium atropurpureun (Siratro), Digitaria sanguinalis (Summer grass) and Zoysia macrantha (Prickly couch).

Table 3: Flora species list Labrador sand dunes

\begin{tabular}{|l|l|l|l|l|c||}
\hline \hline Order & Family & Genus & Species & Common Name & Weed \\
\hline Asparagales & Xanthorrhoeaceae & Dianella & congesta & Flax lily & X \\
\hline Asterales & Asteraceae & Conzya & canadensis & Canadian Fleabane & \\
\hline & Goodeniaceae & Scaevola & calendulacea & Fan Flower & \\
\hline Caryophyllales & Aizoaceae & Carpobrotus & glaucescens & Pigface & X \\
\hline Fabales & Fabaceae & Acacia & sophorae & Coastal Wattle & \\
\hline & & Macroptilium & atropurpureum & Siratro & Yellow Beach Bean \\
\hline & & Vigna & marina & Dune Sedge & $\mathrm{x}$ \\
\hline Poales & Carex & pumila & Summer grass & \\
\hline & Digitaria & sanguinalis & Coastal Lovegrass & \\
\hline & Eragrostis & interrupta & Beach spinifex & \\
\hline & Spinifex & sericeus & Salt couch &
\end{tabular}




\begin{tabular}{|c|c|c|c|c|c|}
\hline & & Zoysia & macrantha & Prickly couch & $\mathrm{x}$ \\
\hline Sapindales & Sapindaceae & Alectryon & coriaceus & Beach Alectryon & \\
\hline Solanales & Convolvulaceae & Ipomoea & pes-caprae & Goat's Foot & \\
\hline
\end{tabular}

Fauna species found at the Labrador dune site are animals of the suborder Caeliferam, the order Lepidoptera and the suborder Anisoptera. A total of 15 crabholes were directly observed during visit one, 18 crabholes were observed during visit two.

\section{Surfers Paradise}

The Surfers Paradise sand dunes are located in the heart of a popular tourist destination, resulting in a high percentage of human impact on the site. This has also contributed to a decreased number of crabholes as well as a decrease in flora density on the foredunes. Fencing around the foredunes could successfully assist in the protection of these dunes. Furthermore, more weeding should be carried out. This sand dune is currently of average health.

A total of 18 species are directly observed within 11 families from 11 orders on the Surfers Paradise dune site (table 4). Of these 18 species, five species are weeds. The most common weed observed is the Cynodon dactylon (Couch grass).

Table 4: Flora species list Surfers Paradise sand dunes

\begin{tabular}{|c|c|c|c|c|c|}
\hline Order & Family & Genus & Species & Common Name & Weed \\
\hline Asparagales & Xanthorrhoeaceae & Dianella & congesta & Flax lily & \\
\hline Asterales & Asteraceae & Sonchus & oleraceus & Common Sowthistle & $x$ \\
\hline Caryophyllales & Aizoaceae & Carpobrotus & glaucescens & Pigface & \\
\hline \multirow[t]{3}{*}{ Fabales } & Fabaceae & Canavalia & rosea & Beach bean & \\
\hline & & Macroptilium & atropurpureum & Siratro & $x$ \\
\hline & & Vigna & marina & Yellow Beach Bean & \\
\hline Fagales & Casuarinaceae & Casuarina & equisetifolia & Horsetail She-Oak & \\
\hline Malpighiales & Euphoribiaceae & Euphorbia & cyathophora & Painted spurge & $x$ \\
\hline Oxalidales & Oxalidaceae & Oxalis & corniculata & Creeping woodsorrel & $x$ \\
\hline Pandanales & Pandanaceae & Pandanus & Spiralis & Pandanus & \\
\hline \multirow[t]{6}{*}{ Poales } & Poaceae & Cynodon & Dactylon & Couch grass & $x$ \\
\hline & & Eragrostis & interrupta & Coastal Lovegrass & \\
\hline & & Imperata & cylindrica & Blady Grass & \\
\hline & & Spinifex & sericeus & Beach spinifex & \\
\hline & & Sporobolus & virginicus & Salt couch & \\
\hline & & Stenotaphrum & secundatum & Buffalo Grass & \\
\hline Proteales & Proteaceae & Banksia & integrifolia & Coastal Banksia & \\
\hline Solanales & Convolvulaceae & Ipomoea & pes-caprae & Goat's Foot & \\
\hline
\end{tabular}

Fauna species found at the Surfers Paradise sand dunes are Chroicocephalus novaehollandiae (Silver gull), Egretta novaehollandiae (White faced heron), Cracticus mentalis (Pied butcherbird), Artamus leucorynchus (White-breasted woodswallow). These animals are of the family Scincidae, animals of the suborder Caeliferam and animals of the order Lepidoptera. A total of 84 crabholes were directly observed during visit one, 19 crabholes were observed during visit two. 


\section{Broadbeach}

The Broadbeach sand dunes have a limited flora ground cover in the hind dunes. More revegetation activities should be established in order to increase the biodiversity. The foredunes are considerably steep, a sign of a lack in root systems. More planting could result in accretion on the foredunes. New weeds have grown between the first and second visit, and it is therefore recommended to undertake more weeding. There is also a range of bird species observed at this study site as well as an increase in observed crabholes indicating that the site is increasing in health. The health of this site is currently average.

A total of 21 species are directly observed within 14 families from 13 orders on the Broadbeach sand dunes (table 5). Of these 21 species, eight species are weeds. The most common weed observed is the Gloriosa Superba (Glory lily).

Table 5: Flora species list Broadbeach sand dunes

\begin{tabular}{|c|c|c|c|c|c|}
\hline Order & Family & Genus & Species & Common Name & Weed \\
\hline \multirow[t]{3}{*}{ Asterales } & Asteraceae & Emilia & sonchifolia & Lilac tasselflower & $x$ \\
\hline & & Sonchus & oleraceus & Common Sowthistle & $x$ \\
\hline & & Taraxacum & officinale & Dandelion & $x$ \\
\hline Caryophyllales & Aizoaceae & Carpobrotus & glaucescens & Pigface & \\
\hline Commenlinales & Commenlinaceae & Commelina & cyanea & Native wandering jew & \\
\hline \multirow[t]{2}{*}{ Fabales } & Fabaceae & Glycine & tomentella & Glycine & $x$ \\
\hline & & Vigna & marina & Yellow Beach Bean & \\
\hline Fagales & Casuarinaceae & Casuarina & equisetifolia & Horsetail She-Oak & \\
\hline Lamiales & Lamiaceae & Vitex & trifolia & Coastal Vitex & \\
\hline Liliales & Colchicaceae & Gloriosa & Superba & Glory lily & $x$ \\
\hline Oxalidales & Oxalidaceae & Oxalis & corniculata & Creeping woodsorrel & $x$ \\
\hline Pandanales & Pandanaceae & Pandanus & Tectorius & Pandanus & \\
\hline \multirow[t]{6}{*}{ Poales } & Cyperaceae & Carex & pumila & Dune Sedge & \\
\hline & Poaceae & Cynodon & Dactylon & Couch grass & $x$ \\
\hline & & Digitaria & sanguinalis & Summer grass & $x$ \\
\hline & & Eragrostis & interrupta & Coastal Lovegrass & \\
\hline & & Spinifex & sericeus & Beach spinifex & \\
\hline & & Sporobolus & virginicus & Salt couch & \\
\hline Ranunculales & Menispermaceae & Stephania & japonica & Snake Vine & \\
\hline Sapindales & Sapindaceae & Alectryon & Coriaceus & Beach Alectryon & \\
\hline Solanales & Convolvulaceae & Ipomoea & pes-caprae & Goat's Foot & \\
\hline
\end{tabular}

Fauna species found at the Broadbeach site are Chroicocephalus novaehollandiae (Silver gull), Manorina melanocephala (Noisy miner), Cracticus tibicen (Australian magpie), Threskiornis moluccusanimals (Australian ibis), Entomyzon cyanotis (Blue-faced honeyeater) and animals of the family Scincidae. A total of 15 crabholes were directly observed during visit one, 23 crabholes were observed during visit two.

\section{North Burleigh}

North Burleigh is the second most popular beach on the Gold Coast, resulting in a highly accessed beach including its sand dunes. The sand dunes have a significant flora density creating a suitable habitat for multiple fauna species. The flora biodiversity has increased between the two visits. In addition, the number of weeds has increased. It is therefore important that more weeding needs to be undertaken at this location. The health of this sand 
dune is currently average. A total of 26 species are directly observed within 17 families from 15 orders on the North Burleigh sand dunes (table 6). Of these 26 species, six species are weeds. The most common weeds observed are the Glycine tomentella (Glycine) and the Chamaesyce hyssopifolia (Hyssop spurge).

Table 6: Flora species list North Burleigh sand dunes

\begin{tabular}{|c|c|c|c|c|c|}
\hline Order & Family & Genus & Species & Common Name & Weed \\
\hline Asparagales & Xanthorrhoeaceae & Dianella & congesta & Flax lily & \\
\hline Asterales & Goodeniaceae & Scaevola & calendulacea & Fan Flower & \\
\hline \multirow[t]{3}{*}{ Caryophyllales } & Aizoaceae & Carpobrotus & glaucescens & Pigface & \\
\hline & & Teragonia & teragonioides & New Zealand spinach & \\
\hline & Portulacaceae & Portulaca & pilosa & Pigweed & \\
\hline Commenlinales & Commenlinaceae & Commelina & cyanea & Native wandering jew & \\
\hline \multirow[t]{4}{*}{ Fabales } & Fabaceae & Acacia & sophorae & Coastal Wattle & \\
\hline & & Canavalia & rosea & Beach bean & \\
\hline & & Glycine & tomentella & Glycine & $x$ \\
\hline & & Macroptilium & atropurpureum & Siratro & $x$ \\
\hline Fagales & Casuarinaceae & Casuarina & equisetifolia & Horsetail She-Oak & \\
\hline Lamiales & Lamiaceae & Vitex & trifolia & Coastal Vitex & \\
\hline Laurales & Lauraceae & Cassytha & $S p p$ & Devil's twine & \\
\hline \multirow[t]{2}{*}{ Malpighiales } & Euphoribiaceae & Chamaesyce & hyssopifolia & Hyssop spurge & $x$ \\
\hline & & Macaranga & tanarius & Macaranga & \\
\hline Malvales & Malvaceae & Hibiscus & Tiliaceus & Cottonwood & \\
\hline Myrtales & Myrtaceae & Leptospermum & Laevigatum & Coastal tea tree & \\
\hline Oxalidales & Oxalidaceae & Oxalis & Corniculata & Creeping woodsorrel & $x$ \\
\hline Pandanales & Pandanaceae & Pandanus & Tectorius & Pandanus & \\
\hline \multirow[t]{5}{*}{ Poales } & Poaceae & Cynodon & Dactylon & Couch grass & $x$ \\
\hline & & Eragrostis & Interrupta & Coastal Lovegrass & \\
\hline & & Imperata & Cylindrical & Blady Grass & \\
\hline & & Spinifex & Sericeus & Beach spinifex & \\
\hline & & Sporobolus & Virginicus & Salt couch & \\
\hline \multirow[t]{2}{*}{ Solanales } & Convolvulaceae & Ipomoea & pes-caprae & Goat's Foot & \\
\hline & Solanaceae & Solanum & Nigrum & Blackberry nightshade & $x$ \\
\hline
\end{tabular}

Fauna species found at the North Burleigh sand dunes are Threskiornis moluccusanimals (Australian ibis), Cracticus mentalis (Pied butcherbird), Trichoglossus moluccanus (Rainbow lorikeet), Alectura lathami (Brush turkey) and animals of the order Lepidoptera. A total of three crabholes were directly observed during visit one, 20 crabholes were observed during visit two.

\section{Palm Beach}

The Palm Beach sand dunes comprise of an extensive strandline zone and foredune. The foredunes as well as the hind dunes are almost completely covered with beach spinifex. The flora biodiversity has decreased over time due to the beach spinifex overgrowing other species and the increase in weeds species. In addition, the amount of crabholes decreased as a result of an increase in human impact and decrease of dune health. More planting on the hind dune and more weeding should be conducted in order to increase the biodiversity and with that, the dune health. The health of this dune is currently poor. 
A total of 14 species are directly observed within eight families from six orders on the Palm Beach sand dunes (table 7). Of these 13 species, four species are weeds. The most common weed observed is the Glycine tomentella (Glycine).

Table 7: Flora species list North Burleigh sand dunes

\begin{tabular}{||l|l|l|l|l||}
\hline \hline Order & Family & Genus & Species & Common Name \\
\hline Asparagales & Amaryllidaceae & Crinum & pedunculatum & River lily \\
\hline Asterales & Asteraceae & Conzya & canadensis & Canadian Fleabane \\
\hline & & Sphagneticola & trilobata & Singapore daisy \\
\hline Caryophyllales & Goodeniaceae & Scaevola & calendulacea & Fan Flower \\
\hline Fabales & Aizoaceae & Carpobrotus & glaucescens & Pigface \\
\hline & Fabaceae & Canavalia & rosea & Beach bean \\
\hline & & Glycine & tomentella & Glycine \\
\hline Poales & & Vigna & marina & Yellow Beach Bean \\
\hline & Poaceae & Cynodon & Dactylon & Couch grass \\
\hline & & Eragrostis & interrupta & Coastal Lovegrass \\
\hline & & Spinifex & sericeus & Beach spinifex \\
\hline Solanales & & Sporobolus & virginicus & Salt couch \\
\hline & Convolvulaceae & Ipomoea & pes-caprae & Goat's Foot \\
\hline
\end{tabular}

Fauna species found at the Palm sand dunes are Chroicocephalus novaehollandiae (Silver gull), Cracticus tibicen (Australian magpie), animals of the order Lepidoptera and species of the suborder Caelifera. A total of 123 crabholes were directly observed during visit one and two. A total of 63 crabholes were recorded during visit three due to an increase in human impact.

\section{Currumbin}

The Currumbin sand dunes have to deal with a high abundance in human impact due to the popular surfing spot located directly in front of the dune site. Trampling is therefore one of the main impacts for these sand dunes, especially on the foredunes. The hind dunes have a high flora density and are still increasing in biodiversity. The number of crabholes observed slightly decreased due to an increase in human impact resulting from increased visitation over the school holiday period. The health of this sand dune is presently good.

A total of 12 species are directly observed within seven families from six orders on the Currumbin sand dunes (table 8). Of these 12 species, three species are weeds. The weeds observed are the Macroptilium atropurpureum (Siratro), Cynodon dactylon (Couch grass) and the Conzya canadensis (Canadian fleabane).

Table 8: Flora species list Currumbin sand dunes

\begin{tabular}{||l|l|l|l|l|c||}
\hline Order & Family & Genus & Species & Common Name & Weed \\
\hline Asterales & Asteraceae & Conzya & canadensis & Canadian Fleabane & $\mathrm{x}$ \\
\hline & Goodeniaceae & Scaevola & calendulacea & Fan Flower & \\
\hline Caryophyllales & Aizoaceae & Carpobrotus & glaucescens & Pigface & \\
\hline Fabales & Fabaceae & Canavalia & rosea & Beach bean & X \\
\hline & & Macroptilium & atropurpureum & Siratro & Yellow Beach Bean \\
\hline & & Vigna & marina & Couch grass & $\mathrm{x}$ \\
\hline Poales & Cynodon & Dactylon & Coastal Lovegrass & \\
\hline & Eoaceae & Eragrostis & interrupta & & \\
\hline
\end{tabular}




\begin{tabular}{|l|l|l|l|l|l||}
\hline & & Spinifex & sericeus & Beach spinifex & \\
\hline & & Sporobolus & virginicus & Salt couch & \\
\hline Solanales & Convolvulaceae & Ipomoea & pes-caprae & Goat's Foot & \\
\hline Unplaced & Dilleniaceae & Hibbertia & scandens & Guinea Flower & \\
\hline
\end{tabular}

Fauna species found at the Currumbin sand dunes are Chroicocephalus novaehollandiae (Silver gull), Thalasseus bergii (Crested tern), Hemidactylus frenatus (House gecko) and animals of the order Lepidoptera. A total of 19 crabholes were directly observed during visit one, a total of 11 crabholes was observed during visit two.

\section{Tugun}

Tugun is a large sand dune with a high flora density on the hind dunes. Diversity is decreasing due to the increased number of weeds. Invasive species cover a total of $40 \%$ of the total sand dune, which is a significant amount. To increase the flora biodiversity as well as the health of the dune, more weeding needs to be undertaken at this site. A decrease in the number of crabholes has been observed over the three visits indicating decreasing health of the dune. However, this sand dune provides a good habitat for a range of bird species due to its coastal vitex, horsetail she-oaks and pandanus trees. The overall health for this sand dune could be considered as poor.

A total of 25 species are directly observed within 13 families from 11 orders on the Tugun sand dunes (table 9). Of these 25 species, 13 species are weeds. This means that more than half of all species observed at this site are weeds. Very common weeds observed are the Conzya bonariensis (Flaxleaf fleabane), Conzya Canadensis (Canadian fleabane) and Euphorbia cyathophora (Painted spurge).

Table 9: Flora species list Tugun sand dunes

\begin{tabular}{|c|c|c|c|c|c|}
\hline Order & Family & Genus & Species & Common Name & Weed \\
\hline Asparagales & Asparagaceae & Asparagus & aethiopicus & Asparagus & $\mathrm{x}$ \\
\hline \multirow[t]{2}{*}{ Asterales } & Asteraceae & Conyza & bonariensis & Flaxleaf fleabane & $\mathrm{x}$ \\
\hline & & Conzya & canadensis & Canadian Fleabane & $x$ \\
\hline \multirow[t]{2}{*}{ Caryophyllales } & Aizoaceae & Carpobrotus & glaucescens & Pigface & \\
\hline & Portulacaceae & Portulaca & Oleracea & Common purslane & \\
\hline Commenlinales & Commenlinaceae & Commelina & Cyanea & Native wandering jew & \\
\hline \multirow[t]{4}{*}{ Fabales } & Fabaceae & Crotalaria & lanceolata & Lance-leaved rattlepod & $x$ \\
\hline & & Glycine & tomentella & Glycine & $x$ \\
\hline & & Macroptilium & atropurpureum & Siratro & $x$ \\
\hline & & Vigna & Marina & Yellow Beach Bean & \\
\hline Lamiales & Lamiaceae & Vitex & Trifolia & Coastal Vitex & \\
\hline \multirow[t]{3}{*}{ Malpighiales } & Euphoribiaceae & Chamaesyce & hyssopifolia & Hyssop spurge & $x$ \\
\hline & & Chamaesyce & ophthalmica & Rock spurge & $x$ \\
\hline & & Euphorbia & cyathophora & Painted spurge & $x$ \\
\hline \multirow[t]{7}{*}{ Poales } & Cyperaceae & Carex & Pumila & Dune Sedge & \\
\hline & & Isolepis & Nodosa & Knobbly club Rush & \\
\hline & Poaceae & Cynodon & Dactylon & Couch grass & $x$ \\
\hline & & Eragrostis & interrupta & Coastal Lovegrass & \\
\hline & & Panicum & maximum & Green Panic & $x$ \\
\hline & & Paspalum & Notatum & Bahia grass & $x$ \\
\hline & & Spinifex & Sericeus & Beach spinifex & \\
\hline Sapindales & Sapindaceae & Alectryon & Coriaceus & Beach Alectryon & \\
\hline
\end{tabular}




\begin{tabular}{||l|l|l|l|l|c||}
\hline \hline Saxifragales & Crassulaceae & Bryophyllum $x$ & houghtonii & Hybrid & $\mathrm{x}$ \\
\hline & & Bryophyllum & pinnatum & Resurrection plant & $\mathrm{x}$ \\
\hline Solanales & Convolvulaceae & Ipomoea & pes-caprae & Goat's Foot & \\
\hline
\end{tabular}

Fauna species found at the Tugun sand dunes are Chroicocephalus novaehollandiae (Silver gull), Thalasseus bergii (Crested tern), Phalacrocorax varius (Pied cormorant), Hirundo neoxena (Welcome swallow), Threskiornis moluccus (Australian ibis), Cracticus tibicen (Australian magpie), Malurus cyaneus (Superb fairy-wren), animals of the order Lepidoptera and animals of the suborders Caelifera. A total of 89 crabholes were directly observed during visit one, 43 crabholes was observed during visit two and 45 crabholes were observes during visit three.

\section{Rainbow Bay}

Rainbow Bay is a very well managed sand dune that does not contain many weeds. However, these sand dunes lack flora biodiversity with only eight different species found, of which six were found during the last visit. Planting new native species could be beneficial for this location. The foredunes are a fluctuating dune to an increase of human impact, resulting in trampling. The overall health of this sand dune is currently good.

A total of eight species are directly observed within five families from five orders on the Rainbow Bay sand dunes (table 10). Of these eight species, one species is a weed. The only weed observed is Cynodon dactylon (Couch grass).

Table 10: Flora species list Rainbow Bay sand dunes

\begin{tabular}{|c|c|c|c|c|c|}
\hline Order & Family & Genus & Species & Common Name & Weed \\
\hline Caryophyllales & Aizoaceae & Carpobrotus & glaucescens & Pigface & \\
\hline Fabales & Fabaceae & Canavalia & rosea & Beach bean & \\
\hline Pandanales & Pandanaceae & Pandanus & Spiralis & Pandanus & \\
\hline \multirow[t]{4}{*}{ Poales } & Poaceae & Cynodon & Dactylon & Couch grass & $x$ \\
\hline & & Eragrostis & interrupta & Coastal Lovegrass & \\
\hline & & Spinifex & sericeus & Beach spinifex & \\
\hline & & Sporobolus & virginicus & Salt couch & \\
\hline Solanales & Convolvulaceae & Ipomoea & pes-caprae & Goat's Foot & \\
\hline
\end{tabular}

Fauna species found at the Palm sand dunes are Chroicocephalus novaehollandiae (Silver gull), Phalacrocorax varius (Pied cormorant), Haematopus fuliginosus (Sooty oystercatcher), animals of the family Scincidae, and animals of the order Lepidoptera. A total of nine crabholes were directly observed during visit one, a total of 31 crabholes were observed during visit two and a total of 30 crabholes during visit three.

\section{Human Impact}

More than 85 percent of Australia's inhabitants live within 100 kilometres of the coast (Australian Government, 2014). Additionally, tourism is an important element for the Australian and local Gold Coast economy. 
A total of 486 sightings of direct human impact were recorded. These records are divided into; domestic animals in dune sites, dog faeces, trampling from kite surfers, litter, trampling from surfers and visitors. The pie chart in figure 2 shows the overall percentage per impact for the ten study sites.

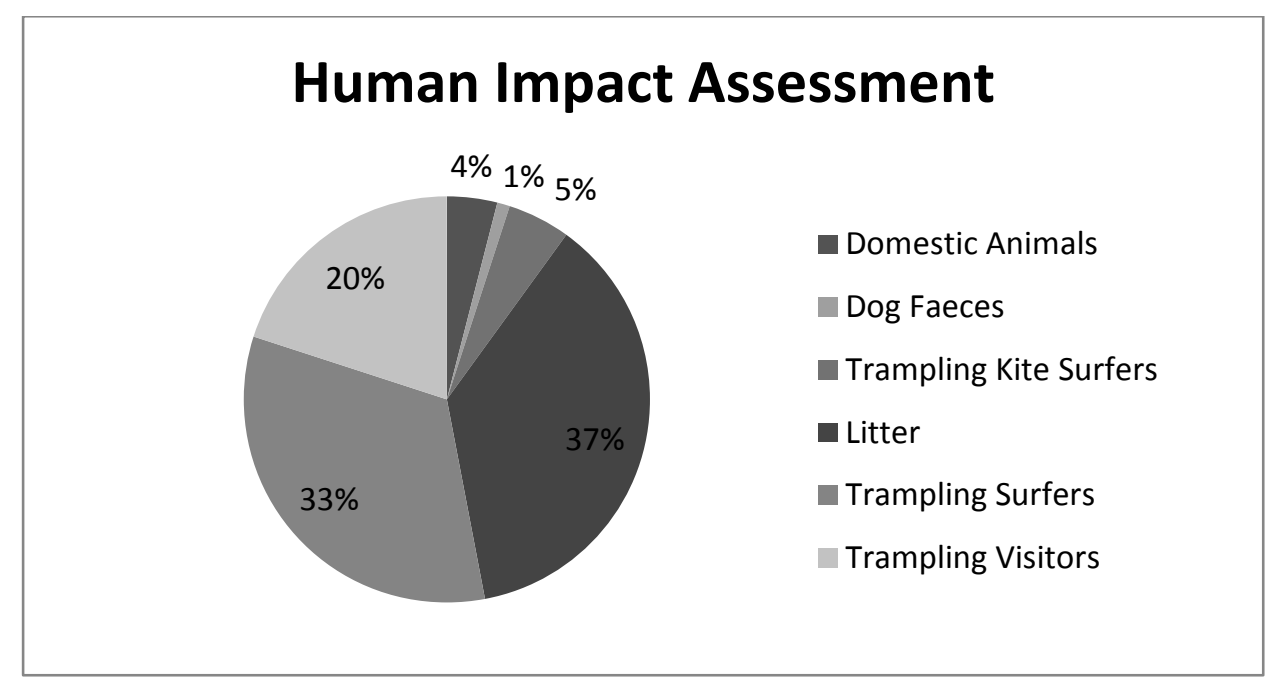

Figure 2: Overall human impact percentages for the DuneWatch study sites

\section{Conclusion}

In urban and suburban environments, such as the Gold Coast region, citizen science programs, including DuneWatch, can match ecological monitoring data (such as human impacts on dune health) with data on human attributes, including eduational/health statistics and participants' residential practices such as pesticide and water use, energy consumption, pet ownership and residential habitat management, to better understand the impacts of cultural and behavioural practices on ecological response variables (Field et al. 2010)

As this is a preliminary analysis of the findings from DuneWatch, no major changes have occurred. However, slight changes at some of the study sites indicate that the dunes are continually changing. More data needs to be collected in order to establish a more accurate database.

As community members are involved in collecting the data, observations could be interpreted in different ways. This can cause fluctuations in the abundance of numbers or in the identification process. It is therefore important that participants take photos when uncertainties arise.

The sand dunes systems are vulnerable ecosystems and are constantly changing due to human impact as well as natural processes. Popular tourist and visitor destinations such as Surfers Paradise, North Burleigh and Currumbin experience a high amount of human impact, through a high amount of trampling. Preliminary results have shown that as a result of the trampling, flora distribution decreases and causes scarping of the foredunes.

Multiple study sites need more revegetation in order to improve the flora biodiversity. Sites such as Rainbow Bay are overall healthy but could benefit from an increase in biodiversity. 
The introduction of new species to this site could be beneficial for the overall health of the ecosystem. Paradise Point and Labrador are sites that are currently in development, it is therefore important to plant more at these study sites in order to increase the flora density as well as the diversity. Both the Broadbeach and Palm Beach hind dunes could use more planting in order to create better root systems at the top of the dunes.

More weeding should be undertaken at nine of the ten study sites. Weeding is essential to the keep the dunes healthy and to provide help to the ecosystem to maintain or increase its biodiversity. Runaway Bay and Tugun have the highest priority for weeding at this moment as their flora is at least $40 \%$ weeds. Labrador should have more weeding undertaken in order the help this new dune site to become healthier.

\section{Authors}

Maggie Muurmans holds qualifications in Wildlife Management with honours in communication and environmental education. She has managed a range of community engagement and conservation programs throughout the world. Her current role is to coordinate the coastal education program as part of the coastal community engagement program on the Gold Coast.

Peta Leahy, with qualifications in coastal engineering, environmental science and natural resource management has occupied various coastal research, program support and educational roles with the Griffith Centre for Coastal Management, throughout the past ten years. Her current role is as the Project Manager of the City of Gold Coast Coastal Research Program.

Rosalinde Brinkman holds qualifications in Wildlife Management. She has been instrumental in the establishment of DuneWatch and collecting the first preliminary data. Rosalinde completed her internship with the Griffith Centre for Coastal Management with a focus on DuneWatch.

\section{References}

Allen, M. A., \& Callaghan, J. (2000). Extreme wave conditions for the South East Queensland coastal region. Environment Techincal Report 32. Brisbane: Environmental Protection Agency.

Beals, M., Gross, L., \& Harrell, S. (1999). Diversity indices: Simpson's D and E. Retrieved 10 8, 2015, from http://www.tiem.utk.edu/

Cooper CB, Dickinson J, Philips T, Bonney R. (2007a) Citizen science is a tool for conservation in residential ecosystems. Ecology and Society 12:11

Department of Environment and Resource Management. (2010). Land Manager's Monitoring Guide, Photopoint Monitoring. QLD: State of Queensland.

Field D, Voss P, Kuczenski T, Hammer R, Radeloff V (2010) Reaffirming social landscape analysis in landscape ecology: a conceptual framework. Society and Natural Resources 16:349-61 
Hughes, N. K., Burley, A. L., King, S. A., \& Downey, P. O. (2009). Standard monitoring techniques - introducing photopoint and observational monitoring. Sydney: Department of Environment and Climate Change NSW.

Irwin A. (2001) Constructing the scientific citizen: Science and democracy in the biosciences. Public Understanding of Sciece 10:1-18

Wilson, D. E., Cole, F. R., Nichols, J. D., Rudran, R., \& Foster, M. S. (1996). Measuring and Monitoring Biological Diversity. Washington, USA: Smithsonian. 